\title{
ANALISIS CLUSTER PENGUNJUNG TEMPAT WISATA \\ (Studi Kasus: Pantai Panjang Bengkulu)
}

\author{
Mimi Kurnia Nengsih, Yesi Indian Ariska \\ Program Studi Manajemen Fakultas Ekonomi Universitas Dehasen Bengkulu \\ mimikurnianengsih@gmail.com
}

\begin{abstract}
ABSTRAK
Mimi Kurnia Nengsih, Yesi Indian Ariska; Penelitian ini bertujuan mengelompokkan pengunjung wisata pantai panjang Bengkulu. Penelitian ini dilakukan melalui pengamatan langsung, wawancara dan pengisian kuesioner terhadap 30 responden. Analisis yang digunakan yaitu analisis cluster. Hasil yang diperoleh yaitu Pengunjung tempat wisata Pantai Panjang Bengkulu di kelompokkan berdasarkan Jenis Kelamin, Pendidikan, Usia, Tempat Asal dan Pendapatan. Berdasarkan Nilai F pada analisis Anova diketahui bahwa perbedaan pengunjung berdasarkan pendidikan memiliki perbedaan yang semakin kecil pada cluster yang terbentuk. Pada penelitian ini terlihat bahwa pengunjung di dominasi oleh tingkat pendidikan SMA. Variable lain yang menjadi dasar pengelompokan pengunjung seperti Jenis Kelamin, Usia, Tempat asal dan Pendapatan terdapat perbedaan yang besar dalam ppembentukan cluster.
\end{abstract}

\section{ABSTRACT}

Mimi Kurnia Nengsih, Yesi Indian Ariska; This study aims to classify visitors to Bengkulu long beach tourism. This research was conducted through direct observation, interviews and questionnaires with 30 respondents. The analysis used is cluster analysis. The results obtained are Bengkulu Long Beach tourist attractions in the group based on Gender, Education, Age, Place of Origin and Income. Based on the F value in the Anova analysis it is known that the difference in visitors based on education has increasingly smaller differences in the clusters formed. In this study it appears that visitors are dominated by high school education. Other variables that form the basis of grouping visitors such as Gender, Age, Place of Origin and Income there are large differences in cluster formation.

Key Words: Long Beach, Tourism, Cluster

\section{LATAR BELAKANG}

Tempat wisata menjadi salah satu ciri khas suatu daerah. Setiap wilayah di Indonesia memiliki keanekaragaman tempat wisata yang mampu menarik wisatawan lebih banyak, baik wiasatawan domistik maupun wisatawan mancanegara. Pengembangan atau pembangunan pariwisata terbukti mampu memberi dampak positif dengan adanya perubahan yang besar dalam kehidupan masyarakat.

Berwisata merupakan merupakan salah satu kebutuhan sekunder yang harus dipenuhi manusia selain kebutuhan utamanya. Kebutuhan untuk berwisata merupakan kebutuhan yang dipenuhi untuk memberikan kenyamanan (faktor amenities). Dewasa ini kegiatan berwisata lebih mengarah pada jenis wisata yang natural atau kembali ke alam (back to nature), hal ini dikarenakan suasana lingkungan wisata yang berbeda dengan rutinitas wisatawan pada umumnya serta kepedulian masyarakat terhadap konservasi dan pelestarian alam yang lebih meningkat (Koranti, et al 2017)

Provinsi Bengkulu secara geografis terletak di tepi pantai Samudera Indonesia (Pantai Barat Pulau Sumatera), diantara 102,16 BT dan 2,4 LS dengan luas wilayah 144,52 Km. Kota Bengkulu merupakan bagian wilayah provinsi Bengkulu yang kaya akan potensi alam diantara obyek wisata yang ada diwilayah pesisir yang cukup dikenal yaitu pantai panjang yang ramai dikunjungi baik pengunjung dari kota Bengkulu, maupun diluar kota Bengkulu.

Wisata alam Pantai Panjang sangat menarik untuk dikunjungi. Tahun 2016 jumlah kunjungan wisatawan mancanegara ke Bengkulu sebanyak 848 wisatawan dan wisatawan nusantara mencapai 491.993 wisatawan. Hal tersebut membuktikan bahwa wisata alam pantai semakin diminati oleh para wisatawan.

Pantai panjang merupakan pantai yang membentang sepanjang $7 \mathrm{Km}$ dengan potensi pasir putih yang bersih dan terletak pada jarak $2 \mathrm{Km}$ dari pusat kota. Luas kawasan pantai secara keseluruhan adalah 178,50 Ha. Sepanjang pantai ditumbuhi oleh pohon cemara. Berbagai aktivitas wisata atau rekreasi pantai yang dapat dilakukan antara lain seperti olah raga air dan pantai, panorama laut, sun set, kegiatan penangkapan ikan, perkemahan dan rekreasi. Dalam rencana umum tata ruang Kota Bengkulu kawasan ini tergolong kawasan hutan lindung dan dimanfaatkan sebagai hutan wisata. Fasilitas umum antara lain 
hotel, restoran, fasilitas rekreasi, fasilitas kios cenderamata, fasilitas utilitas umum serta tersedia sarana jalan raya di sepanjang pantai.

Pantai Panjang sangat ramai dikunjungi pada akhir pekan dan pada hari-hari libur nasional, fenomena ramainya pengunjung wisata pantai panjang ini memberikan inspirasi kepada peneliti untuk mengetahui keberagaman pengunjung dan mengelompokkan pengunjung dalam beberapa variable, sehingga dapat diketahui pengunjung yang dominan berdasarkan variable-variabel yang menjadi karakteristik dalam penelitian ini.

\section{LANDASAN TEORI Wisata}

Pasal 1 Undang-Undang Nomor 9 Tahun 1990 menyebutkan bahwa yang dimaksud dengan wisata adalah kegiatan perjalanan atau sebagian dari kegiatan tersebut yang di1akukan secara sukarela atau bersifat sementara untuk menikmati obyek dan daya tarik wisata.

\section{Pariwisata}

Berdasarkan Undang-Undang Nomor 10 tahun 2009, pariwisata adalah segala sesuatu yang ada hubungannya dengan wisata atau, termasuk pengusahaan objek dan daya tarik wisata serta usaha-usaha yang berhubungan dengan penyelenggaraan pariwisata. Pariwisata bisa disebut kegiatan atau perjalanan seseorang ke daerah lain untuk melihat situasi berbeda dengan daerahnya, dengan maksud untuk refresing, menghilangkan rasa kejenuhan di daerahnya. Pariwisata ada hubungannya dengan kegiatan timbal balik antara tempat wisata dengan pengunjung.

\section{Wisatawan}

Wisatawan adalah orang yang melakukan kegiatan wisata (Undang-Undang Nomor 9 tahun 1990 tentang Pariwisata), sedangkan Keppres No. 9 tahun 1969 tentang pengembangan pariwisata memberi batasan wisatawan adalah setiap orang yang berpergian dari tempat tinggalnya untuk berkunjung ke tempat lain dengan menikmati perjalanannya itu. Dalam kepariwisataan internasional, pengertian wisatawan didasarkan pada hasil konferensi Perserikatan Bangsa-Bangsa tentang perjalanan dan kepariwisataan tahun 1963 menyebutkan bahwa pengunjung (visitor) dibagi atas dua jenis yakni wisatawan (tourist) dan pelancong (excurtionist). Wisatawan adalah mereka yang berkunjung paling sedikit 24 jam di negara yang dikunjungi dengan klasifikasi kunjungan untuk pesiar, hubungan dagang, keluarga, konferensi, dan menjalankan suatu misi. Pelancong (excurtionist) adalah pengunjung sementara yang tinggal kurang dari 24 jam pada destinasi yang dikunjungi dan tidak tinggal untuk menginap melewati malam. Berdasarkan batasan-batasan di atas, dapat diidentifikasikan bahwa seseorang disebut wisatawan apabila:

1. Pejalanan dilakukan dengan sukarela

2. Perjalanan dilakukan dari satu tempat ke tempat lain di luar wilayah tempat tinggalnya.

3. Perjalanan tersebut bersifat sementara waktu.

4. Perjalanan tersebut tidak untuk mencari nafkah.

5. Perjalanan tersebut semata-mata bertujuan untuk: pestar, liburan, kesehatan, belajar, keagamaan, olahraga.

Menurut WTO (World Tourism Organization) definisi wisatawan adalah sebagai berikut:

1. Pengunjung adalah setiap orang yang berkunjung kesuatu negara lain dimana ia mempunyai tempat kediaman, dengan alasan melakukan pekerjaan yang diberikan oleh negara yang dikunjunginya.

2. Wisatawan adalah setiap orang yang bertempat tinggal disuatu negara tanpa memandang kewarganegaraannya, berkunjung ke suatu tempat pada negara yang sama untuk jangka waktu lebih dari 24 jam yang tujuan perjalanannya dapat diklasifikasikan pada salah satu hal berikut ini. a. Memanfaatkan waktu luang untuk untuk rekreasi, liburan kesehatan, pendidikan, keagamaan dan olahraga. b. Bisnis atau mengunjungi keluarga.

3. Darmawisata atau excursionist adalah pengunjung sementara yang menetap kurang dari 24 jam dinegara yang dikunjunginya termasuk orang yang berkeliling dengan kapal pesiar, namun tidak termasuk pesiar yang memasuki negara secara legal, contohnya orang yang hanya tinggal diruang transit pelabuhan udara

\section{Jenis Pariwisata}

Host dan Guest mengklasifikasikan jenis-jenis pariwisata sebagai berikut:

1. Pariwisata Pantai (Marine Tourism), yaitu kegiatan pariwisata yang ditunjang oleh sarana dan prasarana untuk berenang, memancing, menyelam dan olah raga air lainnya, termasuk sarana dan prasarana akomodasi hotel dan restoran. 
2. Pariwisata Etnik (Ethnic Tourism), yaitu peijalanan untuk mengamati perwujudan kebudayaan dan gaya hidup masyarakat yang dianggap menarik/eksotik.

3. Pariwisata Budaya (Culture Tourism), yaitu perjalanan untuk meresapt (terkadang untuk mengalami) suatu gaya hidup yang telah hilang dari ingatan manusta.

4. Pariwisata Rekreasi (Recreational Tourism), yaitu kegiatan pariwisata yang berkisar pada olahraga, menghilangkan ketegangan dan melakukan kontak sosial dalam suasana yang santai.

5. Pariwisata Alam (Ecotourism), yaitu peijalanan dari suatu tempat ke tempat lain yang relatif masih aslilbelum tercemar, dengan tujuan untuk mempelajari, mengagumi, menikmati pemandangan, tumbuhan dan binatang liar, serta perwujudan budaya yang ada/pernah ada di tempat tersebut.

6. Pariwisata Kota (City Tourism), yaitu perjalanan dalam suatu kota untuk melihat/mempelajari, mengagumi, menikmati pemandangan, tumbuhan dan binatang liar, serta perwujudan budaya yang ada/pernah ada di kota tersebut.

7. Kawasan Kota (Resort City), yaitu suatu kota/perkampungan yang mempunyai tumpuan kehidupan pada penyediaan sarana dan prasarana wisata, yaitu penginapan, restoran, olahraga, hiburan dan penyediaan jasa tamasya lain.

8. Pariwisata Agro (Agrotourism, Rural Tourism, Farm Tourism), yaitu peijalanan yang meresapi dan mempelajari kegiatan pertanian, perkebunan, peternakan, kehutanan, dengan tujuan untuk memikirkan swnberdaya alam dan kelestariannya.

9. Urban Tourism, yaitu bentuk pariwisata yang umwn teijadi di kota-kota besar, dimana pariwisata merupakan kegiatan yang cukup penting, namun bukan merupakan kegiatan utama di kota tersebut.

10. Social Tourism, yaitu suatu pendekatan untuk menyelenggarakan liburan bagi kelompok masyarakat berpenghasilan rendah serta orang-orang yang tidak memiliki inisiatif untuk melakukan peijalanan serta orang-orang yang belum mengerti bagaimana cara mengatur suatu peijalanan wisata.

11. Alternative Tourism, yaitu suatu bentuk pariwisata yang sengaja disusun dalam skala kecil, memperhatikan kelestarian Iingkungan dan segi-segi sosial, untuk menandingi pariwisata berskala besar dan keuntungan ekonominya langsung dirasakan oleh masyarakat sebagai pemilik dan penyelenggara jasa pelayanan dan fasilitas pariwisata.

\section{Pengunjung dan Karakteristiknya}

Menurut International Union of Official Travel Organization (IUOTO), pengunjung yaitu setiap orang yang datang ke suatu negara atau tempat tinggal lain dan biasanya dengan maksud apapun kecuali untuk melakukan pekerjaan yang menerima upah.

Pengunjung digolongkan dalam dua kategori, yaitu:

1. Wisatawan (tourist)

Pengunjung yang tinggal sementara sekurang-kurangnya selama 24 jam di negara yang kunjunginya dan tujuan perjalanannya dapat digolongkan kedalam klasifikasi sebagai berikut:

a. Pesiar (leisure), untuk keperluan rekreasi, liburan, kesehatan, studi, keagamaan dan olahraga.

b. Hubungan dagang (business), keluarga, konferensi, misi, dan lain sebagainya.

2. Pelancong (exursionist)

Pengunjung sementara yang tinggal di suatu negara yang dikunjungi dalam waktu kurang dari 24 jam.

Karakteristik pengunjung dapat dibedakan ke dalam dua jenis, yaitu karakteristik sosial-ekonomi dan karakteristik perjalanan wisata. Dalam hal ini karakteristik pengunjung memberikan pengaruh yang tidak langsung terhadap pengembangan pariwisata. Tidak dapat diterapkan secara langsung langkahlangkah yang harus dilakukan hanya dengan melihat karakteristik pengunjung, melainkan perlu melihat keterkaitan dengan persepsi pengunjung.

Pengunjung pada suatu objek wisata memiliki karakteristik dan pola kunjungan, kebutuhan ataupun alasan melakukan kunjungan ke suatu objek wisata masing-masing berbeda hal ini perlu menjadi pertimbangan bagi penyedia pariwisata sehingga dalam menyediakan produk dapat sesuai dengan minat dan kebutuhan pengunjung.

Adapun karakteristik pengunjung meliputi:

1. Jenis kelamin

2. Usia

3. Kota atau daerah asal

4. Tingkat pendidikan

5. Status pekerjaan

6. Status perkawinan

7. Pendapatan 
Sedangkan pola kunjungan responden merupakan alasan utama perjalanan adalah motif atau tujuan utama dilakukannya perjalanan tersebut meliputi:

1. Maksud kunjungan yang merupakan tujuan utama melakukan perjalanan wisata.

2. Frekuensi kunjungan adalah banyaknya kunjungan ke objek wisata yang pernah dilakukan oleh responden.

3. Teman perjalanan adalah orang yang bersama-sama dengan responden melakukan perjalanan wisata.

4. Lama Waktu kunjungan adalah jumlah waktu yang dihasilkan responden selama berada di objek wisata.

5. Besar pengeluaran adalah jumlah pengeluaran atau biaya selama melakukan perjalanan wisata.

\section{KERANGKA ANALISIS}

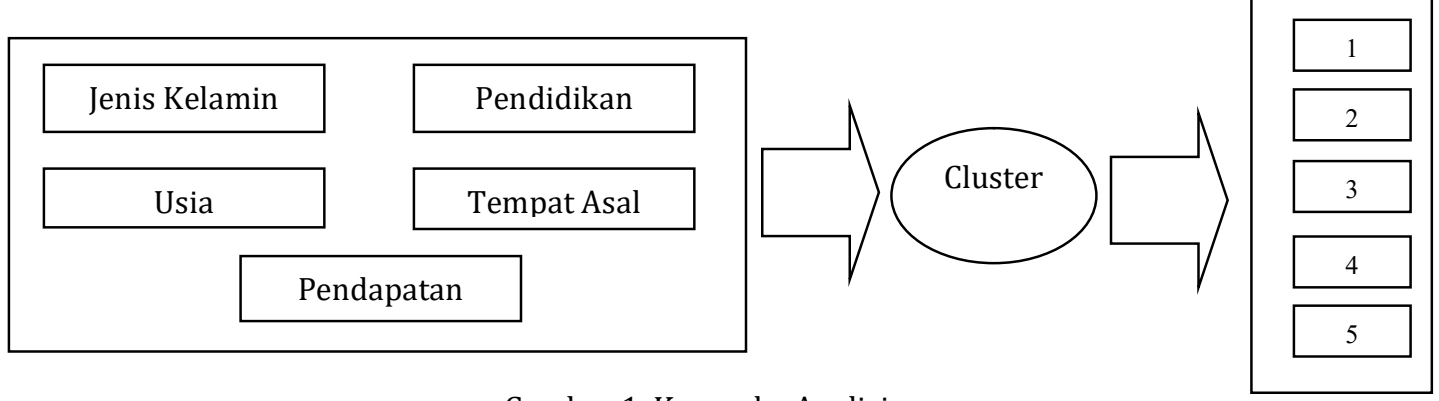

Gambar 1. Kerangka Analisis

\section{METODOLOGI}

Jenis dan Metode Pengumpulan Data

Jenis penelitian ini adalah penelitian eksplorasi yang bertujuan untuk mengelompokkan objek dengan menggunakan metode pengelompokan Analisis Cluster. Pengumpulan data dilakukan melalui pengamatan langsung, wawancara dan pengisian kuesioner. Sampel yang digunakan dalam penelitian ini 30 responden.

\section{Metode Analisis}

Metode analisis yang digunakan dalam penelitian ini yaitu Analisi Custer (Analisis Pengelompokan). Analisis Pengelompokan/ Clustering merupakan proses membagi data dalam suatu himpunan ke dalam beberapa kelompok yang kesamaan datanya dalam suatu kelompok lebih besar dari pada kesamaan data tersebut dengan data dalam kelompok lain (Windarto, 2017). Potensi clustering dapat digunakan untuk mengetahui struktur dalam data yang dapat dipakai lebih lanjut dalam berbagai aplikasi secara luas seperti klasifikasi, pengolahan gambar, dan pengenalan pola (Ong, 2013). Pada proses analisis cluster metode yang digunakan untuk membagi data menjadi subset data berdasarkan kesamaan atau kemiripan yang telah ditentukan sebelumnya. Jadi analisis cluster secara umum dapat dikatakan bahwa:

1. Data yang terdapat dalam satu cluster memiliki tingkat kesamaan yang tinggi.

2. Terdapat dalam suatu cluster yang berbeda memiliki tingkat kesamaan yang rendah

\section{HASIL PENELITIAN DAN PEMBAHASAN}

Sampel yang digunakan pada penelitian ini sebnayak 30 responden, dimana semua responden berdasarkan hasil pengolahan data telah diproses dan tidak ada data yang hilang yang dapat dilihat pada Tabel 1.

Tabel 1. Case Processing Summarya

\begin{tabular}{|c|c|c|c|c|c|}
\hline \multicolumn{6}{|c|}{ Cases } \\
\hline \multicolumn{2}{|c|}{ Valid } & \multicolumn{2}{|c|}{ Missing } & \multicolumn{2}{|c|}{ Total } \\
\hline $\mathrm{N}$ & Percent & $\mathrm{N}$ & Percent & $\mathrm{N}$ & Percent \\
\hline 30 & $100.0 \%$ & 0 & $0.0 \%$ & 30 & $100.0 \%$ \\
\hline
\end{tabular}

a. Squared Euclidean Distance used

Tabel 2 menunjukkan bahwa stage 1: terbentuk 1 cluster yang beranggotakan sampel no 7 dan 22 dengan jarak 0.000 (perhatikan pada kolom Coefficients). Karena proses aglomerasi dimulai dari 2 obyek yang terdekat, maka jarak tersebut adalah yang terdekat dari sekian kombinasi jarak 30 obyek 
yang ada. Selanjutnya lihat kolom terakhir (Next Stage), terlihat angka 6. Hal ini berarti clustering selanjutnya dilakukan dengan melihat stage 6, dimana pada stage 6 terbentuk 1 cluster yang beranggotakan sampel 7 dan 25 dengan jarak 1.394 dan seterusnya.

Tabel 2. Average Linkage (Between Groups) Agglomeration Schedule

\begin{tabular}{|c|c|c|c|c|c|c|}
\hline \multirow[b]{2}{*}{ Stage } & \multicolumn{2}{|c|}{ Cluster Combined } & \multirow[b]{2}{*}{ Coefficients } & \multicolumn{2}{|c|}{ Stage Cluster First Appears } & \multirow[b]{2}{*}{ Next Stage } \\
\hline & Cluster 1 & Cluster 2 & & Cluster 1 & Cluster 2 & \\
\hline 1 & 7 & 22 & .000 & 0 & 0 & 6 \\
\hline 2 & 15 & 19 & .000 & 0 & 0 & 13 \\
\hline 3 & 11 & 18 & .000 & 0 & 0 & 21 \\
\hline 4 & 14 & 17 & .000 & 0 & 0 & 16 \\
\hline 5 & 4 & 16 & .000 & 0 & 0 & 10 \\
\hline 6 & 7 & 25 & 1.394 & 1 & 0 & 22 \\
\hline 7 & 2 & 24 & 1.394 & 0 & 0 & 13 \\
\hline 8 & 5 & 13 & 1.394 & 0 & 0 & 18 \\
\hline 9 & 3 & 27 & 1.529 & 0 & 0 & 18 \\
\hline 10 & 4 & 20 & 1.529 & 5 & 0 & 14 \\
\hline 11 & 21 & 29 & 1.670 & 0 & 0 & 17 \\
\hline 12 & 6 & 12 & 1.670 & 0 & 0 & 19 \\
\hline 13 & 2 & 15 & 2.367 & 7 & 2 & 16 \\
\hline 14 & 4 & 30 & 2.689 & 10 & 0 & 19 \\
\hline 15 & 8 & 10 & 2.923 & 0 & 0 & 26 \\
\hline 16 & 2 & 14 & 3.410 & 13 & 4 & 22 \\
\hline 17 & 1 & 21 & 3.758 & 0 & 11 & 26 \\
\hline 18 & 3 & 5 & 4.520 & 9 & 8 & 27 \\
\hline 19 & 4 & 6 & 4.657 & 14 & 12 & 28 \\
\hline 20 & 23 & 28 & 5.422 & 0 & 0 & 23 \\
\hline 21 & 11 & 26 & 6.116 & 3 & 0 & 23 \\
\hline 22 & 2 & 7 & 6.171 & 16 & 6 & 24 \\
\hline 23 & 11 & 23 & 7.028 & 21 & 20 & 25 \\
\hline 24 & 2 & 9 & 8.296 & 22 & 0 & 25 \\
\hline 25 & 2 & 11 & 8.951 & 24 & 23 & 27 \\
\hline 26 & 1 & 8 & 9.800 & 17 & 15 & 28 \\
\hline 27 & 2 & 3 & 10.881 & 25 & 18 & 29 \\
\hline 28 & 1 & 4 & 11.308 & 26 & 19 & 29 \\
\hline 29 & 1 & 2 & 11.875 & 28 & 27 & 0 \\
\hline
\end{tabular}

Berdasarkan Tabel 2 Cluster Membership diketahui jika yang diinginkan 2 cluster, maka yang menjadi anggota cluster 1 lihat pada kolom "2 clusters" dengan symbol 1, yaitu pegunjung dengan simbol identitas A, D, F, H, J, L, P, T, U, CC dan DD. Jika yang diinginkan 3 cluster, maka yang menjadi anggota cluster 1 dapat lihat pada kolom 3 cluster dengan simbol 1 yaitu pengunjung dengan symbol identitas $A$, H, J, U, CC. Jika yang diinginkan 4 cluster, maka yang menjadi anggota cluster 1 lihat pada kolom 4 cluster dengan simbol 1 yaitu A, H, J, U, CC. Terlihat untuk anggota cluster 1 terjadi kesamaan cluster di bagi 3 cluster atau 4 cluster.

Tabel 3. Cluster Membership

\begin{tabular}{|l|r|r|r|}
\hline Case & 4 Clusters & 3 Clusters & 2 Clusters \\
\hline $1: \mathrm{A}$ & 1 & 1 & 1 \\
$2: \mathrm{B}$ & 2 & 2 & 2 \\
$3: \mathrm{C}$ & 3 & 2 & 2 \\
$4: \mathrm{D}$ & 4 & 3 & 1 \\
$5: \mathrm{E}$ & 3 & 2 & 2 \\
$6: \mathrm{F}$ & 4 & 3 & 1 \\
$7: \mathrm{G}$ & 2 & 2 & 2 \\
$8: \mathrm{H}$ & 1 & 1 & 1 \\
$9: \mathrm{I}$ & 2 & 2 & 2 \\
$10: \mathrm{J}$ & 1 & 1 & 1 \\
$11: \mathrm{K}$ & 2 & 2 & 2 \\
$12: \mathrm{L}$ & 4 & 3 & 1 \\
$13: \mathrm{M}$ & 3 & 2 & 2 \\
$14: \mathrm{N}$ & 2 & 2 & 2 \\
$15: \mathrm{O}$ & 2 & 2 & 2 \\
$16: \mathrm{P}$ & 4 & 2 & 1 \\
$17: \mathrm{Q}$ & 2 & 2 \\
$18: \mathrm{R}$ & 2 & 2 & 2 \\
$19: \mathrm{S}$ & 2 & 2 & 2 \\
$20: \mathrm{T}$ & 4 & 2 & 1 \\
$21: \mathrm{U}$ & 1 & 2 & 2 \\
$22: \mathrm{V}$ & 2 & 2 & 2 \\
$23: \mathrm{W}$ & 2 & 2 & 2 \\
$24: \mathrm{X}$ & 2 & 2 & 2 \\
\hline & 2 & 2 & 2 \\
\hline & 2 & 2 & 2 \\
\hline
\end{tabular}




\begin{tabular}{|l|r|r|r|}
\hline Case & 4 Clusters & \multicolumn{1}{|c|}{ 3 Clusters } & \multicolumn{2}{|c|}{ 2 Clusters } \\
\hline $25: \mathrm{Y}$ & 2 & 2 & 2 \\
$26: \mathrm{Z}$ & 2 & 2 & 2 \\
$27: \mathrm{AA}$ & 3 & 2 & 2 \\
$28: \mathrm{BB}$ & 2 & 2 & 2 \\
$29: \mathrm{CC}$ & 1 & 1 & 1 \\
30:DD & 4 & 3 & 1 \\
\hline
\end{tabular}

Terlihat dalam dendogram, apabila akan dibentuk 2 cluster, maka cluster 1 beranggotakan $\mathrm{G}, \mathrm{V}$, Y, N, Q, O, S, B, X, I,W, BB, K, R DAN Z (sesuai urutan dalam dendogram); dan cluster 2 beranggotakan E, M, C,AA dan seterusnya.

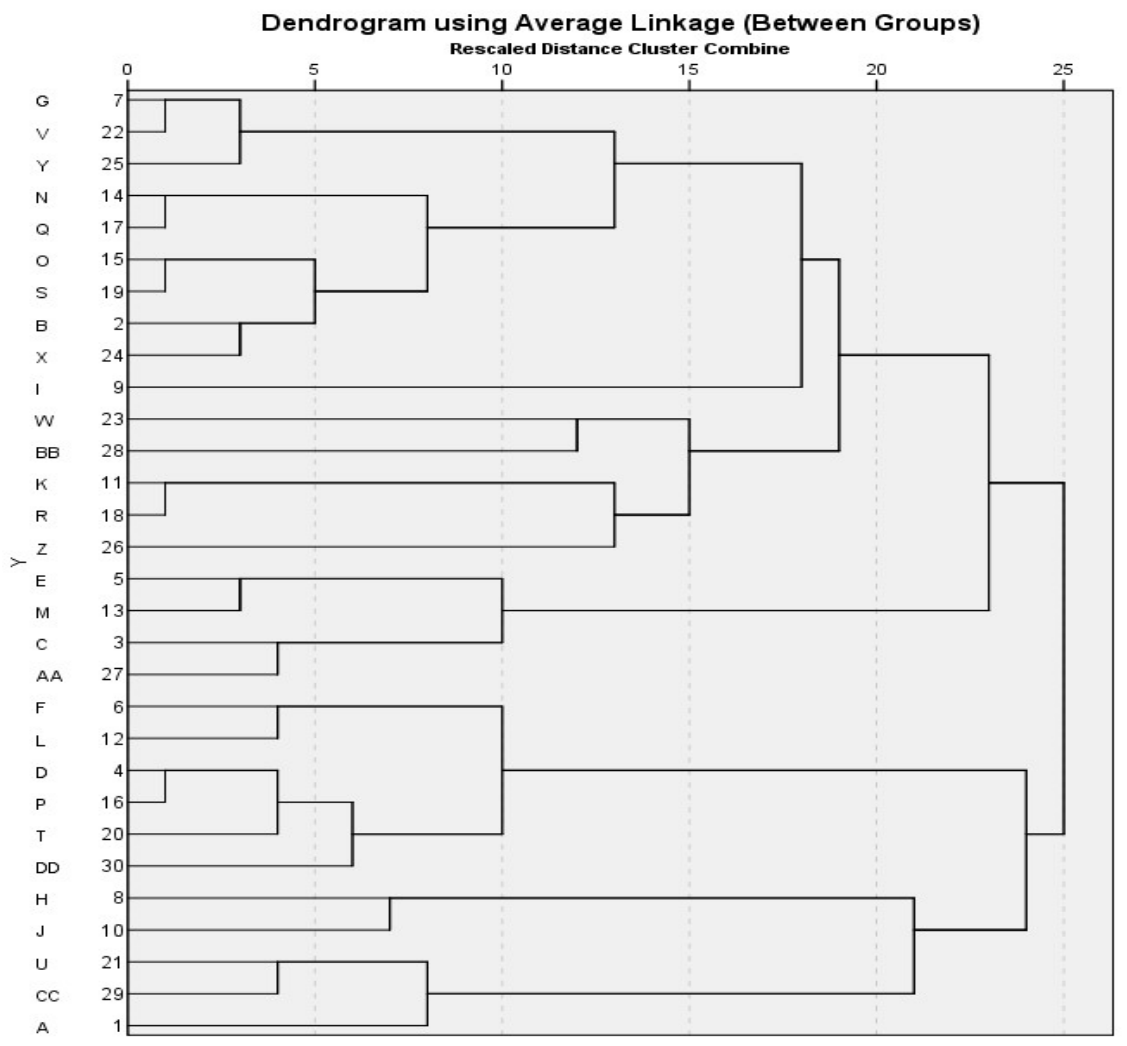

Gambar 2. Dendogram

Tabel 4. Iteration History ${ }^{a}$

\begin{tabular}{|c|c|c|c|}
\hline \multirow[b]{2}{*}{ Iteration } & \multicolumn{3}{|c|}{ Change in Cluster Centers } \\
\hline & 1 & 2 & 3 \\
\hline 1 & 1.577 & 1.350 & 1.385 \\
\hline 2 & .199 & .000 & .218 \\
\hline 3 & .281 & .161 & .227 \\
\hline 4 & .185 & .000 & .271 \\
\hline 5 & .000 & .276 & .348 \\
\hline 6 & .000 & .000 & .000 \\
\hline
\end{tabular}

a. Convergence achieved due to no or small change in cluster centers. The maximum absolute coordinate change for any center is .000 . The current iteration is 6 . The minimum distance between initial centers is 3.947 .

Tabel 4. "Iteration History", dapat diketahui bahwasanya proses iterasi dilakukan sebanyak 3 kali. Proses ini dilakukan untuk mendapatkan cluster yang tepat. Dapat diketahui bahwa jarak minimum antar pusat cluster yang terjadi dari hasil iterasi adalah 3.947. 
Tabel 5. Final Cluster Centers

\begin{tabular}{|l|r|r|r|}
\hline \multirow{2}{*}{} & \multicolumn{3}{|c|}{ Cluster } \\
\cline { 2 - 4 } & 1 & \multicolumn{1}{c|}{2} & \multicolumn{1}{c|}{3} \\
\hline Zscore(Jenis_Kelamin) & .63553 & .00000 & -.95329 \\
Zscore(Pendidikan) & .23691 & .21537 & -.62458 \\
Zscore(Usia) & .45263 & -1.06270 & .64943 \\
Zscore(Tempat_Asal) & -.42700 & -.32846 & 1.05108 \\
Zscore(Pendapatan) & .55644 & -.70070 & .04122 \\
\hline
\end{tabular}

Output Tabel 5. "Final Cluster Centers" dapat diketahui bahwasanya data masih terkait dengan proses standarisasi yang mengacu pada Z-score dengan ketentuan sebagai berikut:

a. Nilai negatif $(-)$ berarti data berada di bawah rata-rata total

b. Nilai positif $(+)$ berarti data berada di atas rata-rata total.

Tabel 6. ANOVA

\begin{tabular}{|l|r|r|r|r|r|r|}
\hline & \multicolumn{2}{|c|}{ Cluster } & \multicolumn{2}{c|}{ Error } & \multicolumn{2}{c|}{} \\
\cline { 2 - 6 } & Mean Square & df & Mean Square & df & F & Sig. \\
\hline Zscore(Jenis_Kelamin) & 6.058 & 2 & .625 & 27 & 9.689 & .001 \\
Zscore(Pendidikan) & 2.129 & 2 & .916 & 27 & 2.323 & .117 \\
Zscore(Usia) & 8.563 & 2 & .440 & 27 & 19.471 & .000 \\
Zscore(Tempat_Asal) & 6.052 & 2 & .626 & 27 & 9.672 & .001 \\
Zscore(Pendapatan) & 4.319 & 2 & .754 & 27 & 5.728 & .008 \\
\hline
\end{tabular}

The $\mathrm{F}$ tests should be used only for descriptive purposes because the clusters have been chosen to maximize the differences among cases in different clusters. The observed significance levels are not corrected for this and thus cannot be interpreted as tests of the hypothesis that the cluster means are equal.

Tabel 6 ANOVA "MS Between" ditunjukkan oleh nilai "Means Square" dalam kolom "Cluster", sedangkan "MS Within" ditunjukkan oleh nilai "Means Square" dalam kolom "Error".

Semakin besar nilai $\mathrm{F}$ dan $(\operatorname{sig}<0,05)$, maka semakin besar perbedaan variabel pada cluster yang terbentuk. Nilai F untuk Pendidikan 2.323 dengan sig 0.117 berarti semakin kecil perbedaan variable pada cluster yang terbentuk. Sedangkan untuk variabel Jenis Kelamin, Usia, dan tempat asal dan Pedapatan dengan nilai sig. < 0,05 menyatakan semakin besar perbedaan variable pada cluster yang terbentuk

\section{KESIMPULAN}

1. Pengunjung tempat wisata Pantai Panjang Bengkulu di kelompok kan berdasarkan Jenis Kelamin, Pendidikan, Usia, Tempat Asal dan Pendapatan.

2. Berdasarkan Nilai $\mathrm{F}$ pada analisis Anova diketahui bahwa perbedaan pengunjung berdasarkan pendidikan memiliki perbedaan yang semakin kecil pada cluster yang terbentuk. Pada penelitian ini terlihat bahwa pengunjung di dominasi oleh tingkat pendidikan SMA.

3. Variable lain yang menjadi dasar pengelompokan pengunjung seperti Jenis Kelamin, Usia, Tempat asal dan Pendapatan terdapat perbedaan yang besar dalam ppembentukan cluster.

\section{SARAN}

Berdasarkan penelitian diketahui pengunjung pantai panjang yang dominan adalah anak-anak muda, maka dari itu peneliti menyarankan untuk dilakukan pengembangan pembangunan sarana dan prasarana di daerah wisata pantai panjang yang akan menarik keberagaman pengunjung dan dapat 
memberikan peluang kepada para pedagang untuk membantu meningkatkan kesejahteraan masyarakat di sekitar pantai panjang.

\section{DAFTAR PUSTAKA}

J. O. Ong. 2013. Implementasi Algoritma K-Means Clustering Untuk Menentukan Strategi Marketing President University. Jurnal Ilmiah Teknik Industri, vol. 12, no. 1, pp. 10 - 20.

Koranti K. 2013. Analisis Pengaruh Faktor Eksternal dan Internal Terhadap Minat Berwirausaha. Proceeding PESAT (Psikologi, Ekonomi, Sastra, Arsitektur, dan Teknik Sipil), pp. E1- E8, 5 Oktober 2013. Bandung: PESAT.

Koranti, et al. 2017 Analisis Preferensi Wisatawan Terhadap SaranaDi Wisata Taman Wisata Kopeng. Jakarta: Universitas Gunadarma.

Windarto, A. P. 2017. Implementasi metode topsis dan saw dalam memberikan reward pelanggan. Kumpulan Jurnal Ilmu Komputer (KLIK), 4(1), pp. 88- 101. 